\title{
Farklı Bakış Açılarına Göre Sosyal Bilgiler Dersinde Değerler Eğitimi
}

\section{Values Education in Social Studies Lesson According to Different Perspectives}

Sevda Gülşah YILDIRIM, Uludağ Üniversitesi Eğitim Fakültesi, sevda yil@mynet.com Sabri BECERIKLİ, Uludağ Üniversitesi Eğitim Fakültesi, beceriklisabri@uludag.edu.tr Muammer DEMİREL, Uludağ Üniversitesi Eğitim Fakültesi, mdemirel@uludag.edu.tr

ÖZ. Araştırma, Sosyal Bilgiler dersinde değerler eğitimi üzerine Sosyal Bilgiler Öğretmenlerinin, Sosyal Bilgiler öğretmen adaylarının, Sosyal Bilgiler dersi gören ortaokul öğrencilerinin ve velilerinin, karşılaştırmalı olarak, görüşlerini ortaya çıkarmayı amaçlamaktadır. Bu araştırmada, genel tarama modeliyle gerçekleștirilmiştir. Veriler, araştırmacılar tarafından hazırlanan açık uçlu soru formlarıyla elde edilmiş ve tümdengelim yoluyla analiz edilmişlerdir. Öğretmen, öğrenci ve velilere göre, aileden kazanıldığı düşünülen başlıca değerler, saygı, sevgi, dürüstlük, yardımseverlik ve hoşgörü değerleridir. Katılımcıların tümüne göre, okulda kazanıldığı düşünülen değerler, sorumluluk ve duyarlılık değerleridir. Veliler, genellikle, okuldan akademik başarıyı destekleyecek değerler (düzenli ve planlı olma, iş birliğine yatkınlık gibi) kazandırılmasını beklemektedirler. Değer edinme yaklaşımı olarak bütün katılımcıların öğretmenin rol-model olması, yaşantısıyla ve davranışıyla örnek olması gerektiğini vurguladı̆̆ı görülmektedir. Öğretmenler doğrudan aktarımı kullanmadıklarını belirtseler bile, öğretmen adaylarının gözlemlerine göre öğretmenler en çok telkin etme yaklaşımını kullanmaktadırlar. Bununla birlikte öğrencilerin ve velilerin bekledikleri yöntemler arasında da telkin etme yaklaşımı yer almaktadır. Sonuç olarak, değerler eğitiminde aile katılımı ve öğrencinin aktifliği önemlidir. Katılımcı sayısının genişletilmesi ve katılımcı kitlenin zenginleştirilmesi önerilmektedir.

Anahtar Sözcükler: Sosyal Bilgiler Dersi, Değerler Eğitimi, Sosyal Bilgiler Öğretmeni, Ortaokul Öğrencileri

\begin{abstract}
The study aimed to examine the opinions of Social Studies Teachers, teacher candidates, middle school students and their parent comparatively on values education in Social Studies Lesson. This study was performed with descriptive survey model, data were received with open-ended questionnaires prepared by researchers and analysed by using deductive approach. According to teachers, students and parents, the main values are respect, love, honesty, helpfulness and tolerance thought that this values are acquired family. According to all participants, values learned in school are responsibility and sensibility. Parents usually expect to gain value supporting academic success from the school. All participants think that teacher should rolemodel and with his/her life and behaviour should be an example to students as value acquisition method. Although teachers state that we don't use inculcation approach, according to the observations of teacher candidates, they prefer the most this approach. The fact remains that inculcation approach is among methods that students and their parents expect. As a result, parent involvement and the activity of students is important in value education. Expanding the number of participants and to enrich type of participants is recommended. Keywords. Social Studies Lesson, Values Education, Social Studies Teacher, Middle School Students
\end{abstract}

\section{SUMMARY}

Purpose and Significance: In recent years, besides knowledge-based education, values education have become a topic that is closely related to scientists. When examined books and articles, the most of the works revealed a single point of view. In this study, on the other hand, aimed to reveal comparatively views of Social Studies teachers, teacher candidates who observe teachers for school experience lesson, middle school students and their parents.

Methodology: In this study, descriptive survey model is adopted. The participants consisted of 20 middle school students, 19 student's guardian, 10 Social Studies teachers and 21 social studies teacher candidates in 2015-2016 academic year. Data were gathered through the open-ended questions which are prepared by researchers. Data was analyzed through deductive. Answers gained from written views tabulated in headings: Values transferred by family, Values transferred by school, Methods preferred by social studies teachers in values education and methods used by teacher 
according to teacher candidates observing them, Expectations of parents and students on preference of methods-techniques which will use for value education.

Results: According to students, parents and Social Studies teachers, commonly, it was seen that values which have been brought by family are respect, love, honesty, tolerance and charitable. According to students, parents and Social Studies teachers, commonly, it was seen that values which have been brought by school are responsibility and sensibility. In addition to this, parents presented an opinion that school should teach values which will assist academic success such as open to cooperation, socialness, have high communication skill, to be democratic, tidy and planned. Apart from these, parents and students dwelled on how teacher should have features rather than methods. For instance, teacher should be caring, encouraging and merry etc. The other result is that teachers mostly have trained values by way of case studies or exemplary figures in the classroom. Differently from teachers, it was found that teacher candidates have thought that teacher frequently use inculcation approachs.

Discussion and Conclusion: In general, value education principally is the responsibility of the family and then the school. The acquisition of values is necessary for the individual both to know oneself and to fit into society. At this point, teacher and parents, even school management, should get together on values education. In addition, teachers should not refrain from inculcation. However, teachers should not forget it that student's love his/her course and teacher at first. The study can be developed with experimental method by utilising data of this study.

\section{Gíriş}

Son yıllarda bilgi temelli eğitimin yanında kişilerin sahip olduğu veya olması gereken ahlaki davranış özellikleri ve bunların eğitimi, bilim insanlarını yakından ilgilendiren bir konu olmuştur. Bu ahlaki davranışlar, günümüzde değerler eğitimi adı altında okullar tarafından öğrencilere kazandırılmaya çalışılan özellikler olarak karşımıza çıkmaktadır. Okulda kazandırılacak değerlerin neler olduğu ve bu değerlerin nasıl kazandırılacağı hala tartışma konusu olmakla birlikte (Wynne, 1989, akt. Dale, 1994; Superka, Ahrens, Hedstorm, Ford ve Johnson, 1976), değerlerin sahip olduğu anlamların kişiden kişiye farklılık göstermesi de ortak bir değer tanımının oluşmamasına yol açmıştır.

Değerlerin tanımı birçok araştırmacı tarafından farklı yönleriyle ele alınmıştır. Değer, İngiliz Dili sözlügüne göre Latince 'valēre' kökünden türemiş, 'valoir' ve 'valuta' hallerinden sonra 'value' olarak son halini almıştır ve göreceli önem veya erdem, bir şeyin layık olduğu saygı anlamını taşımaktadır (http://dictionary.reference.com, http://oxforddictionaries. com). Türk Dil Kurumu (TDK, t.y.) ise, değerleri, bir şeyin önemini belirlemeye yarayan soyut ölçü, bir şeyin değdiği karşllık, kıymet olarak tanımlamıştır. İlgili literatürde yer alan diğer değer tanımlarına bakılacak olursa; Rokeach'a (1973'den akt. Mehmedoğlu, 2006) göre değerler, davranışı yönlendiren ama zorunlu olarak onu gerektirmeyen nesneler, fikirler, davranış vb. şeyler hakkında duyuşsal olarak yüklü düşünceler iken Schwartz ve Bilsky'e (1987, 1990'dan akt. Mehmedoğlu, 2006) göre değerler fikir ve inançlardır, amaç ve davranışlarla ilişkilidirler, durum ötesidirler, davranışların ve olayların seçim ve değişimine rehberlik ederler, taşıdıkları öneme göre sıralanırlar. Erdem (2003) değerleri; bir durumu tercih etme, davranışların nedenlerini belirleyen veya onları değerlendirmede etkili olan anlayış ve önemli görüneni tanımlayarak tercihlerini etkileyen düşünceler olarak; Çağlar (2005), bireylerin düşünce, tutum ve eylemlerinde birer standart olarak ortaya çıkan kültürel öğeler olarak; Yazıcı ve Yazıcı (2011) hayatın anlamını, onu yaşamaya değer kılan tutum ve inançları ifade eden kavram olarak tanımlamaktadır. Yaman, Taflan ve Çolak (2009) değerlerin toplumdaki uyulması gereken ortak davranışlar olduğunu savunurken, Ulusoy ve Dilmaç (2014), bir sosyal yapının varlık, birlik, işleyiş ve devamının sebebi olarak kabul edilen, tasvip ve teşvik gören, korunmaya çalışılan inanışlar olduğunu ifade etmişlerdir. Birçok kişinin benzer ve farklı yönleriyle değer tanımı yapmasının, değerlerin, geçmişten günümüze toplumu bütünleștirici bir kültür yapısının ayrılmaz parçası olmasından kaynaklandığı ileri sürülebilir.

En eski tarihlerden itibaren değerlerin nesilden nesle aktarılması ve böylece toplumların idamesinin sağlanması, bütün toplulukların sorunu olmuştur. Genç nesillerin topluma uyumlu birer 
üye olması, ahlaklı bireylerin yetişmesi, yöneticilerin adil olma gibi değerlere sahip olması, hem Türk tarihinde hem de diğer toplumların tarihinde önemli yer teșkil etmiștir (Binat, 1971; Lickona, 1993).

19. yüzyılın başlarına kadar Batı’da, gençlere ahlaki özellikler Hristiyan öğretiler içerisinde aşılanmıştır. Ancak 20. yüzyıldan itibaren köyden kente göçler, farklı kültürlerin bir arada yaşaması öncelikle demokratik vatandaş yetiştirme gereğini doğurmuş, demokratik değerlerin ortak payda olarak çokkültürlü toplum yapılarına aktarılması, sorumluluğun dini öğretilerin içeriğinden yavaş yavaş okul programlarına alınmasını sağlamıștır (Purpel, 1998'den akt. Ekși ve Katılmıș, 2014).

Amerika'da, 20. yüzyılın ilk on yılında eğitsel programların kalbi olan karakter eğitimi, 1930'da Hartshorne ve May tarafından yürütülen bir çalışma sonrasında okul programlarında önemini yitirmiş olmasına rağmen, 1960'lardan itibaren tekrar okul programlarında yer alması gerekliliği gündeme gelmiştir (Dale, 1994). Amerika'da ve diğer toplumlarda özellikle 1990'lardan itibaren okullarda değerler eğitimi çeşitli yaklaşımlarlarla ders programlarında yerini almıştır (Keskin, 2010).

Lickona (1993) yapmış olduğu çalışmalar sonucunda toplumsal yaşantıdaki ahlaki çöküntünün karakter eğitimini gerekli kıldığını belirtmiştir. 1994'te profesyonel araştırma kuruluşu Phi Delta Kappan tarafından yürütülen çalışma sonucunda katılımcıların \%90'ının temel değerlerin devlet okullarında öğretilmesi lehine cevap verdikleri ortaya çıkarılmıştır (akt. Dale, 1994).

Aileyi, ahlaki yargıların başlangıç noktası olarak kabul eden Durkheim (2010), asıl ahlak eğitiminin okulların sorumluluğunda olduğunun bir diğer büyük savunucusudur. Durkheim'e (2010) göre, ahlak her zaman için toplumsal bir olgudur. Modern-laik bir ahlaka sahip bir toplumun oluşmasında eğitimcinin, öğretmenin hayati bir rolü vardır. Okullarda değerler eğitiminin verilmesi gerektiğinin diğer bir gerekçesi de öğrencilerin okula öncelikle ailelerinden ve sonrasında çevre, akran, medya gibi faktörlerden almış oldukları farklı değerler ile bașlamaları ve sonucunda kime göre doğru-yanlış, kime göre iyi-kötü kavramı arasında kendi içlerinde çatışma yaşamalarıdır (Buzelli ve Johnston, 2002'den akt. Demirhan İşcan, 2011).

Türk tarihinde değer eğitimini İslam öncesi ve sonrası şeklinde incelemek daha anlamlı olacaktır. İslamiyet öncesinde ve sonrasında Türklerde değer eğitimi, ahlak eğitimi olarak verilmiştir.

İslamiyet'ten önce ahlaki özelliklerin kaynağının Gök-tanrıdan alınan "koruyuculuk" görevi olduğu, bu koruyuculuğun insan sevgisini beraberinde getirdiği kabul edilmiş, toplulukları oluşturan her bireyin yaşananlardan ibret alması düşüncesiyle meydanlara kitabeler dikilmiştir (Kafesoğlu, 2014). Göktürklerden kalan Orhun kitabelerinde devlet başkanına ve halka hitap edilerek, devletin bekası için gerekli iyi karakter özellikleri vurgulanmıştır (Gömeç, 1997). Binlerce yıllık tarihe sahip Türklerin temel özelliklerinin "yaşama disiplini, birlik ve beraberlik, toplum kurallarına bağlllık, kişisel ve ortak sorumluluk, ilim aşkı, yoksullara, kimsesizlere, acizlere yardım fikri, sabır, temkin, basiret, doğruluk, güzellik ve iyilik sevgisi olduğu belirtilmiştir. Türk ahlakının temelini yansıtan bu değerlerin ise nesilden nesile gelmesi destanlar ve destanları vurgulu, sazlı anlatan ozanlar vasıtasıyla gerçekleşmiştir (Binat, 1971). Ayrıca çocuğa önce geçici bir ad verilmesi, sonra bir kahramanlık ve mücadele gösterisi, bir başarıyı göstermesi ile ad koyulması (Akyüz, 2011), Türklerin eskiden beri değer eğitimine verdiği önemi ve çabayı örnekler niteliktedir.

İslamiyet'in kabulüyle birlikte Türk toplumlarında ahlak eğitimi islami öğretilere dayanmıştır. İslam anlayışı aşırılıklardan uzak, dengeli ve uyumlu bir hayat tarzı ortaya koymuştur. Bu hayat tarzını Ayet ve Hadislerden temel alan islam filozoflarının ahlak görüşleri müslüman Türk devletlerinin eğitim anlayıșının öncüsü olmuștur. Ahlak eğitimleri formal ve informal șekilde medreselerde, camilerde, tekkelerde ve esnaf teșkilatlarında yürütülmüștür. Keza Osmanlı İmparatorluğu'da ahlaki öğretilerini islami anlayışı temelli kurmuştur. Osmanlı medreselerinde müstakil bir ahlak dersi 1914'te programlara girmiştir. Fakat bu tarihe kadar ahlak dersinin medreselerin programlarında bulunmamasına rağmen özellikle din dersleri olmak üzere çeşitli derslerin içeriklerinde ahlaki öğretilere yer verilmiş, toplumsal değerler bireylere öğretilmiştir (Kaya, 2013). Müstakil olarak ahlak dersleri ise Tanzimat döneminde açllmaya başlanan modern mekteplerin programlarında yer almaya başlamıştır (Ağırakça, 2012). II. Abdülhamid döneminde ahlak derslerinin üzerinde daha çok durulmuş, ahlak ve din derslerinin saatlerinin arttırılması yönünde çalışmalar yapılmıştır (Gündüz, 2013). Sultan Hamid devrinde devlete, saltanata, dinî değerlere bağlı, güzel ahlâklı gençlerin yetiştirilmesi eğitimin amacı olmuştur (Ağırakça, 2012). Verilmek istenen değer anlayışı sadece ahlak dersleri kapsamında olmamış, din dersleri içerik 
bakımından her zaman ahlaki öğretilerle işlenmiştir (Nurdoğan, 2005). Esasen geçmişin değer anlayışı günümüzden çok büyük farklılıklar göstermemiştir. Anne-baba sevgisi, büyüklere karşı saygılı olma, sabırlı, düzenli, çalışkan olma gibi temel değerlerin değişmesi gibi bir durum olmamıştır (Ali İrfan, 1317). Aynı șekilde 1913 tarihli Mekatib-i İbtidaiyye ders müfredatında Musahabat-ı Ahlakiyye dersinde verilen değerler incelendiğinde günümüzdeki programla benzer değerlerin yer aldığı görülmüştür. 1922 tarihli İlk, Orta Tedrisat Mektepleri müfredat programında Malumat-ı Medeniyye dersiyle öğrencilere demokratik değerler edindirilmeye çalıșılmıştır. Bu derste ümmetçiliğin yanında ağırlıklı bir şekilde milliyetçilik değerine vurgu yapılmıştır (Keskin, 2008). 1924 programında Musahabat-ı Ahlakiyye ve Malumat-ı Vataniye adlı derste ahlak esaslarının çocuklara telkin edilerek öğretilmesi amaçlanmıştır. Bu dersin, ahlak kurallarını çocukların vicdanında yaşatacak sohbetler şeklinde verilmesi planlanmıștır (İlk Mektepler Müfredatı Programı, 1340). 1926 tarihli İlk Mektep Müfredat programından 1968 İlkokul programına kadar Yurt Bilgisi adıyla programda yer almış ve genellikle mevcut yönetimin ilkeleri öğrencilere bu ders ile kazandırılmaya çalıșılmıştır (Keskin, 2008).

1968 programında Sosyal Bilgiler adıyla birleștirilen derslerde yine toplumun değerleri önemsenmiştir. Özellikle 2005 yılında uygulamaya konan Sosyal Bilgiler Ders Programında doğrudan verilecek değerler belirlenmiş ve sınıf derecesine göre ünitelere dağıtılmıştır. Ayrıca programda yer alan değer eğitimi yaklaşımları bir öneri olarak sunulmuş ve ders içeriğinde değerler eğitiminin, bu yaklaşımlardan birinin tercih edilerek verilmesi gerektiği belirtilerek öğretmenlerin öğrenciye buradaki değerleri kazandırması beklenmiștir. Uygulamadaki program, değerler eğitimini ahlakın, karakterin, çokkültürlülügün, demokratik yaşamın eğitimi gibi eğitim modellerini içinde barındıran şemsiye bir terim olarak kabul etmektedir (Milli Eğitim Bakanlığı -MEB- Sosyal Bilgiler Ders Programi, 2005).

Veugelers'e (2000) göre ise değerler eğitimi, değerleri, okullarda ahlaki ortam ve müfredat sayesinde transfer etme, sağlamlaştırma anlamını taşımaktadır. Değerlerin nasıl transfer edilmesi gerektiği sorusundan yola çıkılarak tarihten günümüze çeșitli yaklaşımlar ortaya konmuştur. Telkin Etme, Ahlaki Muhakeme, Değer Analizi, Değer Belirginleștirme, Aksiyon Öğrenme, Gözlem Yoluyla Öğrenme, Örtük Program gibi yaklaşımlarla değerler eğitimi verilmeye çalışılmıştır (Superka ve ark., 1976). Sosyal Bilgiler Ders Programında önerilen bazı yaklaşımlar kısaca şu şekilde açıklanmaktadır:

- Telkin Etme (inculcation): Bu yaklaşımın amacı, bazı ayrıcalıklı değerlerin içselleştirilmesini mümkün kılmak ve bu değerleri aşılamaktır. Ayrıca öğrencilerin bu değerleri yansıtmasını teşvik eder (Demirhan İşcan, 2011).

- Değer Belirginleştirme (values clarification): Bu yaklaşımın temeli bireyin kendi yaşamında neyin önemli olduğunu nasıl belirlediklerine dayanmaktadır. Üç aşamadan oluşur. Seçme, ödüllendirme ve davranış. Öğretmenin müdahalesi olmadan, seçmiş oldukları değer ya da ahlak konularının belirginleștirmesini ve seçtikleri üzerine düşünmelerini sağlamayı amaçlamaktadır (Ulusoy ve Dilmaç, 2014).

- Değer Analizi (analysis): Bu yaklaşım, mantıksal düşünmede ve bilimsel süreç kullanmada, öğrencilerin kendi değerlerini kavramsallaştırmasında, değerler arasında ortak bağlantıları formüle ederken analitik ve mantıklı bir süreç takip etmesinde öğrencilere yardım etmek için kullanılabilir (Demirhan İșcan, 2011).

- Ahlaki Muhakeme (moral development): İlk kez John Dewey tarafından ortaya atılmıștır. Dewey, ahlaki yargıları üç seviyeye ayırmıș, sonrasında bu teori geliştirilerek ahlaki yargı seviyeleri altıya çıkarılmıștır. Bu yaklaşımda, verilen örnek durum üzerinde kişinin seçmiş olduğu yargı ve seçme sebebi, ahlaki yargı dönemlerine göre ayrılmaktadır. Burada önemli olan, kişinin yargısını oluşturan nedenin ortaya çıkarılmasıdır (Kohlberg, 1975).

- Örtük Program (hidden curriculum): Eisner, örtük programın kapsamını toplantılar, kıyafet düzenlemeleri, öğrenciyi izleme ve diğer bütün kültürel özellikleri aracılığıyla okulun öğrencilere dolaylı olarak öğrettiği her şey olarak belirlemektedir (akt. Ekşi ve Katılmış, 2014). Bu yaklaşımlar dışında karakter eğitimi, vatandaşlık eğitimi ve ahlak eğitimi adı altında da değerler eğitimi verilmiştir (Akbaş, 2008).

Literatür incelendiğinde değer eğitimiyle ilgili nicel çalışmaların daha ağırlıklı olduğu, uygulamalı çalışmaların sınırlı olduğu görülmüștür. Özellikle, Türkiye'de yapılan çalışmalarda 
öğretmenlerin değer kazandırma noktasında eğitimine yönelik çalışmalara ihtiyaç olduğu tespit edilmiştir (Gültekin, 2014).

Ulusal alanda değerler eğitimi üzerine yapılan ve incelenen çalışmalara bakıldığında; öğretmen, öğretmen adayı, öğrenci veya veli görüşlerinin ortaya çıkarıldığı çalışmalarda öğrencilerin, değeri neden öğrenmeleri gerektiği ile ilgili açıklama bekledikleri, çocukların, o değeri kazanmanın neden önemli olduğuna ikna edilmesi gerektiği gibi sonuçlar ortaya çıkarılmıştır. Ayrıca herkesin ortak düşüncesi, rol-model olunmasıdır. Söylenen şey ile davranış arasında tutarlılık beklenmektedir (Balcı ve Yanpar Yelken, 2013; Çelikkaya ve Filoğlu, 2014; Kurtdede Fidan, 2009; Memişoğlu, 2013; Oğuz, 2012; Tay, Durmaz ve Şanal, 2013; Tay ve Yıldırım, 2009; Yazar, 2012; Yıldırım, 2009; Yılmaz, 2013). Değer eğitimi üzerine yapılan deneysel çalışmaların sonuçlarına bakıldığında; uygulanan etkinliklerin deney grubu lehine sonuçlandığı ve belirlenen değerleri kazanmada olumlu etkiye sahip olduğu görülmüştür. Çalışmalardan çıkarılan ortak sonuç ise çocukların aktif katıldığı çeşitli etkinlikler ile değerler verilmesi ve çocuk, değerler üzerine düşünmesinin sağlanması gerektiğidir (Katılmış, Ekşi ve Öztürk, 2011; Yiğittir ve Yalçınkaya, 2009).

Değerler eğitimi açısından Sosyal Bilgiler ders kitaplarını inceleyen çalışmalara göre, ders kitaplarında kullanılan yaklaşımların ağırlıklı olarak telkin etme olduğu, bazı yerlerde değer analizine yer verildiği (Ersoy ve Şahin, 2012), programda verilen değerler açısından bilimsellik, kültürel mirasa duyarlılık, hak ve özgürlüklere saygı ve barıș değerlerinin kazanımlarla ilișkili olduğu ve ders kazanımlarının değerleri kazandırmada yetersiz kaldığı belirtilmektedir (Tonga ve Uslu, 2015). Bunlar yanında ders kitaplarında değerlerin en çok düz metin ve gerçek görsel materyaller aracılığı ile verildiği belirlenmiştir (Topkaya ve Tokcan, 2013).

Diğer incelenen değerler eğitimi çalışmalarının (Adıgüzel ve Ergünay, 2012; Demirbaş ve Çelikkaya, 2012; Demirhan İșcan, 2011; Kurtdede Fidan, 2013) sonuçları genel olarak değerlendirildiğinde ortaya çıkan ifadeler şunlardır:

- Telkin edilen değerler, çocuklar tarafından içselleştirilemezse otorite olmadığı zaman anlamsızlaşır.

- Herkesten önce değer kazandırmada temel sorumluluk ailenindir. Okul, sonraki yaşantılardan sorumludur. Okulun bu konudaki temsilcisi ise öğretmendir.

- Öğretmen ve öğretmen adaylarının, değer yaklașımları, değer edindirme yöntemleri üzerine bilgileri yetersizdir. Bu konuda hizmet içi seminer verilebilir.

- Çocukların değerleri benimsemeleri önemsenmelidir.

Uluslararası alanda incelenen çalışmalardan ve eserlerden (Dale, 1994; Durkheim, 2010; Kinnier, Kernes ve Dautheribes, 2000; Kohlberg, 1975; Lickona, 1993, 1997; Schrier, 2015; Schwartz, 1992; Veugelers, 2000) çlkarılan genel sonuçlar şunlardır:

- Toplum yapısındaki bozulmalar için karakter eğitimi şarttır.

- Öğretmenler ne kadar önemsedikleri değerleri yansıtmak istemeseler bile, seçtikleri öğretim yöntem ve tekniği bile bunu yansıtır. Bundan kaçış yoktur.

- Değerler, kültürden bağımsız değildirler ve görecelidirler.

- Yurtdışındaki değer eğitimleri son yıllarda bilgisayar temelli oyunlara yönelmektedir. Ancak şimdiye kadar bu konuda yapılmış bir deneysel çalışma mevcut değildir.

- Okul, değerlerden sorumludur. Çocuğun laik bir eğitim alması okul ile sağlanır.

- Sınıf ortamının demokratik olması, değerlerin kazandırılması için şarttır.

- Değerler hem evrenseldir hem de kültüre göre çeşitlilik gösterebilir. Ancak her ikisinde de adalet, kendine saygı, başkalarına saygı, alçakgönüllülük, özdenetim, davranışın sorumluluğunu üstlenme, diğer canlılara ve çevreye duyarlı olma gibi değerler ortaktır.

Elbir ve Bağcı (2013), değerler eğitimi üzerine yapılmış lisansüstü çalışmaları değerlendirdikleri araştırmalarında, tezlerin büyük çoğunlukla yüksek lisans seviyesinde yapıldığını tespit etmişlerdir. Değerler üzerine yapılan lisansüstü çalışmalar giderek çoğalmaktadır. Son senelere doğru yapılan çalıșmaların ağırlıklı yöntemi deneysel modele dönmektedir. İlköğretim öğrencilerine yönelik uygulamalı yapılan lisansüstü düzeyindeki çalışmaların sonucunda, araștırmacı tarafından hazırlanan ve uygulanan etkinliklerin değer eğitimi açısından olumlu katkı sağladığı, seçilen değerleri kazandırdığı tespit edilmiştir (Ersoy, 2013; Izgar, 2013; Katılmış, 2010). Ayrıca incelenen tezlerden genel olarak ortaya çıkarılan sonuç, öğretmenlerin değerler eğitiminin 
öğretimi sırasında kullanabilecekleri çağdaş yöntem ve teknikler hakkında bilgilendirilmeleri gerektiğidir. Öğretmenlerin değerler eğitiminde kullandıkları yöntem üzerine yapılan çalışmaların sonucunda öğretmenlerin genellikle telkin etme yöntemini kullandıkları, belli bir sistem izlemedikleri, değer eğitimi noktasında bilgilerini yetersiz buldukları ve kendi deneyimlerinden yola çıkarak bu eğitimleri vermeye çalıştıkları ortaya çıkarılmıştır. Bu yöntemler dışında genellikle atasözleri ve deyimlerden, örnek olaylardan yararlandıkları belirtilmiştir (Çengelci, 2010; Yalar, 2010). Ayrıca Kurtdede Fidan (2013), yapmış olduğu çalışmada, sınıf öğretmenlerinin şiirlerin ve okuma parçalarının çocukların eğlenerek değerleri daha iyi kazanmasını sağladığını, sözlü ve yazılı edebi ürünler aracılığı ile ulusal ve evrensel değerlerin daha kolay kazandırılacağına inandıklarını ortaya koymuştur. Öğretmenlerin kullandıkları yöntemin yanında rol-model olması da gereklidir. Çünkü hem öğretmen kendini ne kadar tarafsız görürse görsün davranışlarıyla bir şekilde bunu yansıtacaktır hem de öğrenciler karşısında bir otorite olarak doğru davranışların pekişmesini sağlayan örnek olacaktır (Lickona, 1997; Yıldırım, 2014; Veugelers, 2010).

Ülkemizde bütün derslerin programlarında dolaylı olarak değerlerin kazandırılmasına yer verilmiştir. Sosyal Bilgiler dersine bu misyon doğrudan yüklenmiş ve ünitelere dağıtılmış șekilde belirtilen 20 değerin (adil olma, aile birliğine önem verme, barış, bağımsızlık, bilimsellik, çalışkanlık, dayanışma, duyarlılık, dürüstlük, estetik, hoşgörü, misafirperverlik, özgürlük, sağlıklı olmaya önem verme, saygl, sevgi, sorumluluk, temizlik, vatanseverlik, yardımseverlik) öğrencilere kazandırılması gerektiği belirtilmiştir. Bu sebeple öğretmenlere değer kazandırmada tercih edebilecekleri bazı değer eğitimi yaklaşımları da tavsiye edilmiştir (MEB, 2005 Sosyal Bilgiler Ders Programı). Ancak Memişoğlu (2013) yaptığı çalıșmada, Sosyal Bilgiler Öğretmenlerinin büyük bir çoğunluğunun, değer eğitimi ile ilgili bilgilerinin yeterli olmadığını ifade etmiş̦tir. Özellikle Sosyal Bilgiler Öğretmenleri üzerine yapılan çalışmalarda, öğretmenlerin değer eğitimi yaklaşımları (değer açıklama, değer analizi, ahlaki muhakeme gibi) hakkında pek bilgi sahip olmadıkları, ilk olarak rol-model olarak değer kazandırmayı yöntem seçtikleri, daha sonra sınıf içi tartışmalarla, drama etkinlikleriyle, gezigözlem gibi yöntemlerle değer kazandırmayı tercih ettikleri ortaya çıkarılmıştır (Memişoğlu, 2013; Yılmaz, 2013). Öğrenciler ise öğretmenlerden değerleri en çok telkin ederek, kendilerini sevdirerek ve benimseterek kazandırmalarını beklediklerini ifade etmişler, en az ise hikâyelerle aktarmalarını tercih ettiklerini belirtmişlerdir. Ayrıca sevgi, saygı ve bilimsellik değerleri, velilere göre en çok kazandırılması gereken değerlerdir (Tay, Durmaz ve Şanal, 2013).

Değer eğitimine ilişkin öğretmen adayları üzerine yapılan çalışmaların sayısal olarak daha fazla olduğu görülmektedir. Çalışmaların sonucunda, öğretmen adaylarının yöntem olarak en çok rolmodel olmayı, ders verici hikâyeleri, en az ise telkin etmeyi tercih ettikleri ortaya çıkarılmıştır. Ayrıca öğretmen adayları, kazandırılmak istenen değerlerin velilere anlatılması gerektiğini ifade etmişlerdir. Etkinlik olarak ise drama etkinlikleri ve gezi-gözlem ilk sıralarda yer almaktadır (Kurtdede Fidan, 2009; Oğuz, 2012; Yılmaz, 2013). Hangi değerlerin kazandırılmasına öncelik verileceği konusunda öğretmen adaylarının Yıldırım (2009) yaptığı çalışmada ilk sırada vatanseverlik; Oğuz (2012) evrenselcilik, yardımseverlik ve güvenlik; Yılmaz (2013) ise vatanseverlik, bağımsızlık, adil olma değerlerini tercih ettiklerini belirtmişlerdir. Sosyal Bilgiler dersinde değerlerin kazandırılmasına ilişkin veliler ise kazandırılması gereken en önemli değerlerin saygı, vatanseverlik, dürüstlük ve sevgi olduğunu ifade etmişlerdir (Tay ve Yıldırım, 2009).

İncelenen çalışmalardan hareketle, bu çalıșma Sosyal Bilgilerde değerler eğitimine karşılaştırmalı olarak bakması açısından genel literatür çalışmalarından farklılaşmaktadır. Araştırma, Sosyal Bilgiler dersinde değerler eğitimi üzerine Sosyal Bilgiler Öğretmenlerinin, öğretmen adaylarının, Sosyal Bilgiler dersi gören ortaokul öğrencilerinin ve velilerinin, karşılaştırmalı olarak, görüşlerini ortaya çıkarmayı amaçlamaktadır. Özellikle, araştırmanın, Sosyal Bilgiler Öğretmenlerinin kullandıkları yöntemler üzerine görüşlerine ek olarak öğretmen adaylarının gözlem verilerinden yararlanılarak değerler eğitiminin uygulamadaki haline örnekler sunması açısından bu alanda çalışma yapan araştırmacılara katkı sağlayacağı düşünülmektedir. Araştırmanın amacına uygun olarak şu sorulara cevap aranmaya çalışılmıştır:

1. Aileden çocuklara aktarılan değerlere ilişkin veli, öğrenci ve öğretmenlerin görüşleri nedir?

2. Çocukların okulda kazandıkları değerlere ilişkin veli, öğrenci ve öğretmenlerin görüşleri nedir? 
3. Değer kazandırma yöntem-teknik tercihi konusunda Sosyal Bilgiler Öğretmenlerinin kullandıkları yöntemler nedir ve öğretmen adaylarının gözlemlerine göre Sosyal Bilgiler Öğretmenlerinin kullandığı yöntem-teknikler nelerdir?

4. Değer kazandırma için kullanılacak yöntem-teknik tercihi konusunda veli ve öğrencilerin beklentileri nelerdir?

\section{YÖNTEM}

\section{Araştırmanın Modeli}

Araștırma, genel tarama modeliyle gerçekleștirilmiștir. Tarama modelleri, geçmiște ya da halen var olan durumu var olduğu şekliyle betimlemeyi amaçlayan araştırma yaklaşımlarıdır. Tarama modelinde amaçların ifade edilişi genellikle, soru cümleleri ile olur. Bunlar, "nedir?", "ne ile ilgilidir?" ve "nelerden oluşur?" gibi sorulardır (Karasar, 2014). Tarama çalışmaları, bireylerin tutumlarını, eylemlerini, fikirlerini ve inançlarını belirleme ihtiyacı duyulduğunda tercih edilebilecek bir yöntemdir (Christien, Johnson ve Turner, 2015).

\section{Katılımcılar}

Katılımcıların belirlenmesinde seçkisiz olmayan örnekleme yöntemlerinden uygun örnekleme tercih edilmiştir. Katılımcıları 2015-2016 Eğitim-Öğretim döneminde, devlete bağlı bir ortaokulda öğrenim gören beşinci sınıf kademesinde 10, altıncı sınıf kademesinde 6, yedinci sınıf kademesinde 4 olmak üzere toplam 20 öğrenci, 18'i anne, 1'i baba olmak üzere toplam 19 veli ile söz konusu dönemde üç devlet ortaokulunda görev yapan 7'si kadın, 3'ü erkek toplam 10 Sosyal Bilgiler Öğretmeni ve bu öğretmenleri okul deneyimi dersi kapsamında gözlemleyen 12'si kadın, 9'u erkek toplam 21 Sosyal Bilgiler Öğretmenliği bölümü öğrencisi oluşturmaktadır.

\section{Verilerin Toplanması ve Analizi}

Araştırmacılar tarafından açık uçlu soru formu hazırlanmış ve çalışma gruplarına sunulmuştur. Açık uçlu sorular, araştırmacl, insanların ne düşündügünü bilmek istediğinde veya bir değişkenin boyutları iyi belirlenmediğinde önemlidir (Christien, Johnson ve Turner, 2015). Açık uçlu soru formu hazırlanırken alan ile ilgili literatür taranmış, araștırmacılar tarafından geçici soru maddeleri yazılmıştır. Geçici soru maddeleri alanında uzman iki kişi tarafından incelenmiş, anlaşılabilirliği açısından bir Türkçe öğretmenine sunulmuş ve gerekli düzeltmeler yapıldıktan sonra forma son şekli verilmiştir. Bu yazılı sorular temelde aynı soru köküne sahip olmalarına rağmen, çalışma gruplarının durumlarına uygun hale getirilmiştir. Örneğin kullanılan/tercih edilen yöntemi ortaya çıkarmak amacıyla ortaokul öğrencilerine "Sosyal Bilgiler Öğretmeninizi göz önüne aldığınızda, değerleri hangi yöntemle, nasıl kazanmayı beklersiniz?" sorusu sorulurken, öğretmen adaylarına "Uygulama okulundaki Sosyal Bilgiler Öğretmenini göz önüne aldığınızda, ders esnasında değerlerin hangi yöntem ile kazandırıldığını gözlemlediniz? sorusu sorulmuştur. Uygulama grubuna cevaplaması için yeterli zaman tanınmıştır.

Toplanan veriler, betimsel analiz yöntemiyle daha önce belirlenen temalar altında tablo haline getirilmiştir. Temaların oluşturulmasında araştırma soruları ile ilgili literatür dikkate alınmış ve araștırmacıların fikir birliği ile ortak temalar belirlenmiștir. Kodlamaların güvenirliğini sağlamak amacıyla, veriler iki araştırmacı tarafindan ayrı ayrı kodlanmış ve ortak temalar altında birleştirilmiştir. Oluşturulan kod ve temalar karşılaştırılmış, üzerinde anlaşmazlığa düşülen verilerde üçüncü araştırmacının görüşüne başvurulmuştur. Veriler üzerinde anlaşmazlıklar giderilerek temalar ve kodlamalarda tam bir mutabakata varılmıştır. Her açık uçlu soru için, her grubun cevabının yer aldığı tablolar, karşılaştırılmalı olarak sunulmuş ve cevap verilme sıklığını yansıtması açısından frekanslarına tabloda yer verilmiştir.

\section{BULGULAR}

Araştırmanın bu kısmında, açık uçlu sorulardan elde edilen verilerin karşılaştırmalı olarak tablo halinde sunumu yapılmıştır.

Aileden çocuklara aktarılan değerlere ilişkin veli, öğrenci ve öğretmen görüşleri nedir? sorusuna ilişkin veriler Tablo 1'de yer almaktadır. 
Tablo 1. Aileden çocuklara aktarılan değerlere ilişkin veli, öğrenci ve öğretmen görüşlerine ilişsin veriler

\begin{tabular}{|c|c|c|c|c|c|}
\hline $\begin{array}{l}\text { Velilerin Çocuklarına } \\
\text { Kazandırdıklarını } \\
\text { Düşündükleri Değerler }\end{array}$ & $f$ & $\begin{array}{l}\text { Öğrencilerin Aileden } \\
\text { Aldıklarını } \\
\text { Düš̈ündükleri } \\
\text { Değerler } \\
\end{array}$ & $f$ & $\begin{array}{l}\text { Sosyal Bilgiler Öğretmenlerine } \\
\text { Göre Çocukların Aileden } \\
\text { Aldıkları Değerler }\end{array}$ & $f$ \\
\hline Saygl & 14 & Dürüstlük & 14 & Sevgi & 3 \\
\hline Dürüstlük & 8 & Saygi & 13 & Saygi & 3 \\
\hline Sevgi & 8 & Sevgi & 8 & Misafirperverlik & 3 \\
\hline Yüksek özgüvenli olma & 7 & Adil olma & 4 & Paylașımcılık & 2 \\
\hline Hoşgörü & 6 & Cevreye duyarlılık & 3 & Temizlik & 2 \\
\hline Yardımseverlik & 5 & Ahlaklılık & 3 & Aile birliğine önem verme & 1 \\
\hline Ahlaklılık & 5 & Eşitlik & 2 & Çalıșkanlık & 1 \\
\hline Sorumluluk & 5 & Özgürlük & 2 & Dürüstlük & 1 \\
\hline Çevreye duyarlılık & 4 & Hoşgörü & 1 & Barıș & 1 \\
\hline Paylaşımcllık & 3 & $\begin{array}{l}\text { Alçakgönüllülük, } \\
\text { mütevazılık }\end{array}$ & 1 & Hoşgörü & 1 \\
\hline $\begin{array}{l}\text { Alçakgönüllülük, } \\
\text { mütevazilık }\end{array}$ & 3 & Sorumluluk & 1 & Yardımseverlik & 1 \\
\hline Vatanseverlik & 2 & Yardımseverlik & 1 & Dayanıșma & 1 \\
\hline
\end{tabular}

Tablo-1'e bakıldığında, her üç örneklem grubunun aile içerisinde kazanılan değerler konusunda hemfikir oldukları değerlerin saygı, sevgi, dürüstlük, hoşgörü ve yardımseverlik olduğu ortaya çıkmıştır. Ancak öğrenciler, adil olma, eşitlik, özgürlük gibi değerleri aileden edindiklerini belirtseler de ne velilerin ne de Sosyal Bilgiler Öğretmenlerinin aynı görüşte olmadıkları görülmektedir. Aynı şekilde velilerin belirtmiş olduğu vatanseverlik ve yüksek özgüvenli olma değerlerinin aile tarafından öğretildiğine ilişkin fikir, diğer çalışma gruplarında yer almamaktadır. Sosyal Bilgiler Öğretmenleri ise genellikle ev ortamında daha rahat kazanılabilecek temizlik, aile birliğine önem verme, misafirperverlik, dayanışma gibi değerleri belirtmişlerdir. Elde edilen diğer bir veriye göre, öğrencilerin büyük çoğunluğu $(n=19)$ değerleri öncelikle aileden kazandıklarını, okulun ya da öğretmenlerin değer kazandırmada ikinci sırada olduğunu $(n=12)$ belirtmektedirler.

Çocukların okulda kazandıkları değerlere ilişkin Sosyal Bilgiler Öğretmenlerinin, velilerin ve gözlem yapan öğretmen adaylarının görüşleri nedir? sorusuna ilișkin veriler Tablo 2'de yer almaktadır.

Tablo 2. Cocukların okulda kazandıkları değerlere ilișkin Sosyal Bilgiler Öğretmenlerinin, velilerin ve gözlem yapan öğretmen adaylarının görüșlerine ilișkin veriler

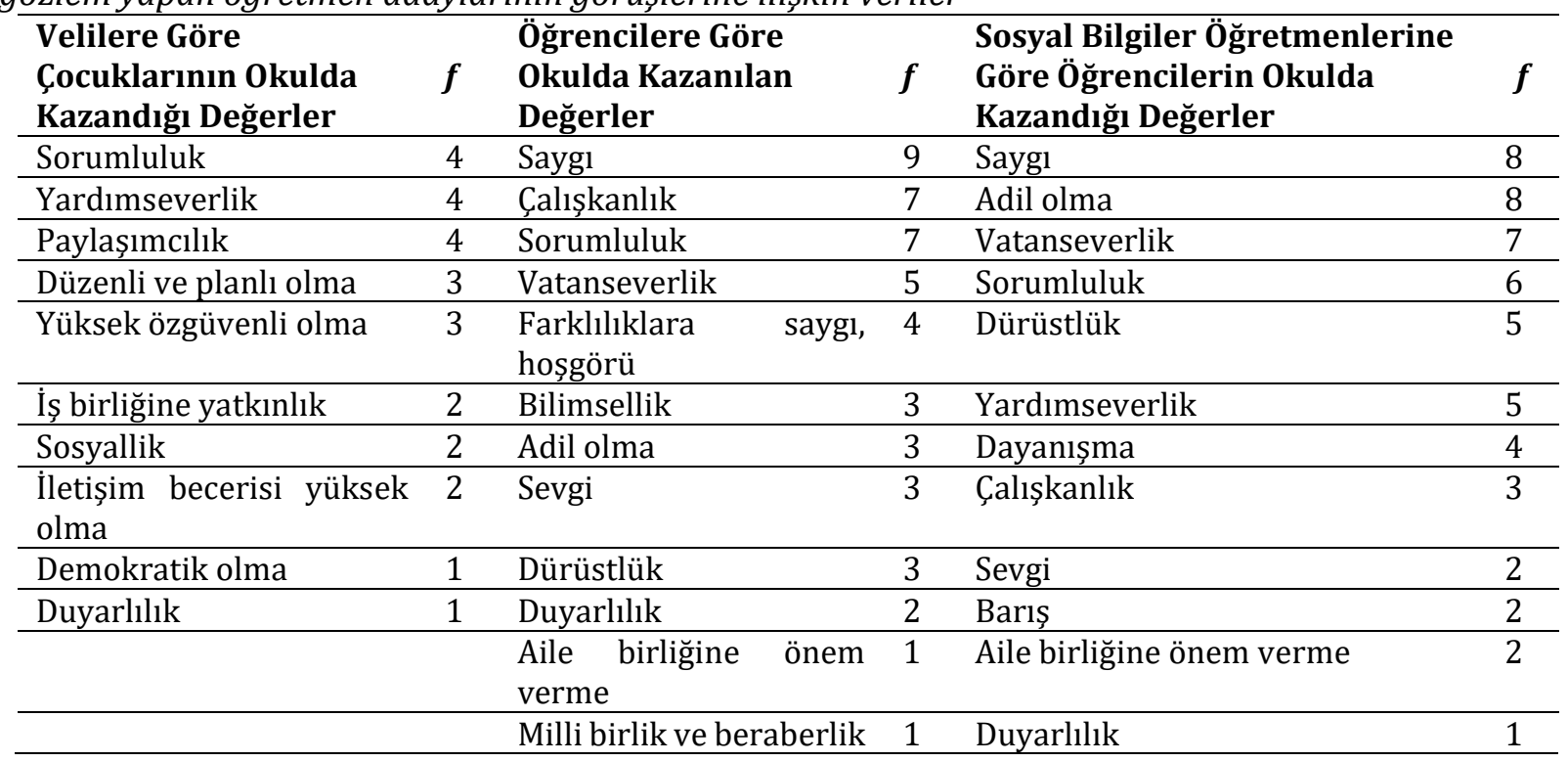


Tablo-2'ye bakıldığında, her üç örneklem grubunun da ortak değerleri sorumluluk ve duyarlılıktır. Okulda kazandırıldığını düşündüğü değerler açısından veliler, çoğunlukla akademik başarıyı destekleyecek kazanımlar çerçevesinde görüş bildirmişlerdir. Ancak ne öğretmenlerin ne de öğrencilerin görüşlerinde velilerin bekledikleri düzenli ve planlı olma, iş birliğine yatkınlık gibi özelliklerin yer almadığı görülmektedir. Öğretmenlerin görüşlerine bakıldığında ise belirttikleri değerlerin hem okulda hem de ailede kazandırılması gerektiğini düşündükleri görülmektedir. Ancak okulda kazandırılan değerlerin sayısına bakıldığında, öğretmenlere göre okul bu konuda daha fazla sorumluluğa sahiptir. Ayrıca öğrencilere göre vatanseverlik, bilimsellik, çalışkanlık, milli birlik ve beraberlik gibi değerler okulda kazandırılan değerler arasındadır. Okulda kazandıklarını düşündükleri değerlerin birçoğunu ailede de kazandıklarını belirtmiş olmalarına rağmen, bu sayılan değerleri ailede kazandıkları değerler arasında belirtmemişlerdir.

Değer kazandırma yöntem veya teknik tercihi konusunda Sosyal Bilgiler Öğretmenlerinin kullandıkları yöntem-teknikler nedir ve öğretmen adaylarının gözlemlerine göre Sosyal Bilgiler Öğretmenlerinin kullandığı yöntem veya teknikler nelerdir? sorusuna ilişkin veriler Tablo 3'te yer almaktadır.

Tablo 3. Sosyal Bilgiler Öğretmenlerinin sınıf içi değerler eğitiminde tercih ettiğini belirttiği yöntemteknikler ve öğretmen adaylarının gözlemlerine göre kullanıldıkları yöntem-tekniklere ilişsin veriler

\begin{tabular}{llll}
\hline $\begin{array}{l}\text { Sosyal Bilgiler Öğretmenlerinin } \\
\text { Değerleri Kazandırmada Tercih } \\
\text { Ettiği Yöntemler }\end{array}$ & $\boldsymbol{f}$ & $\begin{array}{l}\text { Öğretmen Adaylarına Göre Sosyal Bilgiler } \\
\text { Ögretmenin Değer Kazandırmada Kullandı̆̆ı } \\
\text { Yöntemler }\end{array}$ & $\boldsymbol{f}$ \\
\hline Örnek olay & 8 & Düz anlatım & 8 \\
\hline Drama & Soru-cevap & 6 \\
\hline & Örnek olay & 4 \\
\hline & Beyin fırtınası & 1 \\
\hline & Tartışma & 1 \\
\hline
\end{tabular}

Tablo-3'e göre, öğretmenlerin değerleri kazandırırken kullandığı yöntemlerin başında örnek olayları sınıf ortamına çeşitli yollarla sunmak olduğu tespit edilmiştir. Öğretmen adayları ise Sosyal Bilgiler Öğretmenlerinin değerleri en çok düz anlatım, soru-cevap ve örnek olay yöntem ve teknikleri ile kazandırmaya çalıştıklarını gözlemlediklerini belirtmişlerdir. Öğretmen adaylarının bu soruya verdiği diğer yöntem cevapları, değer eğitimi yaklaşımları noktasında, adayların bilgi yetersizliğini de yansıttığı söylenebilir. Öğretim yöntem ve teknikleri bilgilerine dayanarak verilen bazı yöntem cevaplarının (beyin firtınası, gösterim vb.) daha çok dersin işleniş şekli ile ilgili olduğu düşünülmektedir. Tablo-3'te belirtilen yöntem-teknikler dışında, öğretmenler, değer kazandırma için farklı sınıf içi çalışmalar gerçekleştirdiklerini de belirtmişlerdir. Öğretmenler, öğrencilerin empati kurmasını sağlayarak, onlara sorumluluk vererek bazı değerleri kazandırmaya çalıştıklarını ifade etmişlerdir. Sosyal Bilgiler öğretmen adaylarının gözlemlerine göre ise öğretmenler, söz konusu yöntem-teknikler dışında, öğrencilere sınıf içinde sorumluluklar veya görevler vererek ve çeşitli etkinlikler ile değer kazandırmaya çalıșmaktadırlar.

Değer eğitimi yaklaşımları açısından bakıldığında, Sosyal Bilgiler Öğretmenlerinden bazıları $(\mathrm{n}=2)$, sosyal öğrenme yaklaşımı kapsamında, öğrencilere rol-model olmayı tercih ettiklerini belirtmişlerdir. Sosyal Bilgiler öğretmen adaylarının gözlemlerine dayalı olarak belirttikleri yaklaşımlar ise sırasıyla telkin etme $(n=8)$, rol-model olma $(n=2)$ ve değer belirginleştirme/değer açılama $(n=1)$ yaklaşımlarıdır. Öğretmen adaylarının aksine, öğretmenlerden telkin etme/aktarma/aşılama yaklaşımını kullandıklarına dair bir yanıt alınmamıştır. Bu veri ise öğretmenlerin aslında telkin etmek istemediklerini ancak derslerde ister istemez bu yaklaşımı kullandıklarını gösterebilir. Çünkü örnek olay ve kişilerin seçimini de çoğunlukla öğretmen yapmaktadır.

Değer kazandırma için kullanılacak yöntem-teknik tercihi konusunda veli ve öğrencilerin beklentileri nelerdir? sorusuna ilişkin veriler Tablo-4'te yer almaktadır. 
Tablo 4. Değer kazandırma için kullanılacak yöntem-teknik veya değer eğitimi yaklaşımı tercihi konusunda veli ve öğrencilerin beklentilerine ilișkin veriler

\begin{tabular}{llll}
\hline $\begin{array}{l}\text { Velilerin Değer Kazandırmada } \\
\text { Öğretmenden Beklentileri }\end{array}$ & $\boldsymbol{f}$ & $\begin{array}{l}\text { Öğrencilerin Değer Kazanımı Yöntemi } \\
\text { Açısından Öğretmenlerden Beklentileri }\end{array}$ & $\boldsymbol{f}$ \\
\hline Öğretmenin öğrenciye örnek olması & 3 & Örneklendirerek anlatmalı & 5 \\
\hline Değerleri anlatarak & 2 & Aktivitelerle, etkinlikler yoluyla & 5 \\
\hline Doğrudan yașatarak & 2 & Yanlışları kizmadan söyleyerek & 3 \\
\hline & Tatlı dil, güler yüzle anlatarak & 3 \\
\hline & Ilgili davranarak & 2 \\
\hline & Film ya da belgesel ile & 1 \\
\hline & Uygulamalı olarak & 1 \\
\hline & Oyunlarla & 1 \\
\hline & Rehberlik derslerinin içeriğinde & 1 \\
\hline & Rol-model olarak & 1 \\
\hline & Drama ile & 1 \\
\hline & Özgün fikirlerle destekleyerek & 1 \\
\hline
\end{tabular}

Tablo-4 incelendiğinde, velilerin yöntem olarak sınırlı bilgiye sahip oldukları ya da beklentilerinin fazla olmadığı söylenebilir. Öğretmenlerden ilk olarak bekledikleri örnek olmaları, rol-model olmalarıdır. Diğer seçimlere bakıldığında ise değerlerin anlatılması gelmektedir. Öğretmenlerin kaçındığı bir yöntem olan telkin etmenin aslında veliler tarafından beklenildiği söylenebilir. Öğrenciler ise çeşitli yöntemler ortaya sunarak fikirlerini sunmuşlardır. En çok tercih edilen yöntemlerin örnekler ile anlatılmasıdır. Değerlerin aktarımında kahramanlardan yararlanılması, örnek kișilerin sunulması öğretmenlerinde zorlanmayacağı bir yöntem olarak karşımıza çıkmaktadır. Etkinlikler yoluyla değerlerin kazandırılması da çoğu öğrenci tarafından tercih edilen yöntem olduğu görülmektedir.

Elde edilen diğer verilere göre, velilerin değerlerin kazandırılmasında çoğunlukla öğretmenlerin özelliklerinden bahsetmektedirler. Veliler, değer kazandırmada tercih edilecek yaklaşım veya yöntemden çok öğretmenin nasıl olması gerektiği üzerinde durmuşlar ve gerekli gördükleri öğretmen özelliklerini sıralamışlardır (ilgili, güler yüzlü, yol gösterici, yüreklendirici, disiplinli, bilimsel, dürüst, anlayışlı, sevecen, bireysel farklılıkları gözeten, güven verici gibi). Öğrencilerin de öğretmenlerden benzer tavırlar bekledikleri bulgusuna rastlanılmıștır. Tatlı dil ile anlatsın, kızmasın, ilgili davransın, güler yüzle söylesin gibi ifadeler, yöntemden çok öğretmenden beklenen davranışları yansıtmaktadır. Bu sebeple hem velilerin hem de öğrencilerin, öğretmenlerin özelliklerine yönelik beklentiler içinde oldukları söylenebilir.

\section{TARTIŞMA VE SONUÇ}

Bu çalışmada, Sosyal Bilgiler dersine doğrudan yüklenen değerler eğitimi misyonunun farklı bakış açllarından değerlendirmesini yapmak, öğretmenlerin, öğretmenleri gözleyen öğretmen adaylarının, öğrencilerin ve velilerinin gözünden Sosyal Bilgiler dersinde verilen değerler eğitimini irdelemek amaçlanmıştır. Araştırma sonunda ulaşılan genel sonuçlar şunlardır:

Öğretmen, öğrenci ve velilerin cevaplarından alınan verilere dayalı olarak, ailede kazanıldığı düşünülen başlıca değerler, saygı, sevgi, dürüstlük, yardımseverlik ve hoşgörü değerleridir. Ayrıca öğrencilerin büyük çoğunluğu $(\mathrm{n}=19)$ değerlerin ailede kazanıldığını düşünmektedirler. Bu durum, Tay ve Yıldırım (2009) tarafından yapılan velilerin \%68'inin değerler eğitiminin ailede verilmesi gerektiğini ortaya koydukları çalışma ile örtüşmektedir. Benzer olarak, Yıldırım (2009) sınıf öğretmenleriyle yaptığı çalışmasında, öğretmenlerin de değerler eğitiminin öncelikle ailede sonra okulda verilmesi gerektiğini düşündüklerini ortaya çıkarmıştır.

Okulda kazanıldığı düşünülen ve katılımcıların hem fikir olarak beyan ettiği ortak değerler, sorumluluk ve duyarlılık değerleridir. Veliler, genellikle, okuldan akademik başarıyı destekleyecek yönde değerler kazandırılmasını beklemektedirler. Velilerin, iş birliğine yatkınlık, sosyallik, iletişim becerisi yüksek olma, demokratik, düzenli ve planlı olma gibi değerleri öğretmene/okula bıraktığı; ancak sevgi, dürüstlük, saygı gibi kişisel özelliklere vurgu yapılan değerleri kendilerinin kazandırdığını düşündüğü sonucuna ulaşılmıștır. Tay ve Yıldırım'ın (2009) çalışmasında, veliler değer kazanmada gerekçe olarak başarılı olmak, toplumsallaşmak, çocukların kendilerini 
geliştirmesini belirtmişlerdir. Bu gerekçelere bakıldığında, yine daha çok akademik başarıyı destekleyici görüşün ağırlıkta olduğu görülebilir. Bunun yanında hem öğrenciler hem de velileri, öğretmenin özelliklerine yönelik beklentiler içerisindedirler. Örneğin ilgi göstererek, kızmadan, tatlı dil güler yüzle anlatım gibi. Tay, Durmaz ve Şanal (2013), Sosyal Bilgiler dersini alan ortaokul öğrencileriyle yapmış oldukları çalışmada, benzer bulguya rastlamışlardır. Çalışmada, öğrencilerin büyük çoğunluğunun değerleri kazanırken öğretmenin bağırmadan, kendini sevdirerek ve benimseterek vermesini beklediklerini belirtmişlerdir.

Öğretmenler, en çok saygı, adil olma ve vatanseverlik değerleri üzerinde durmaktadırlar. Öğrenciler de aynı şekilde, öğretmenlerin en çok saygı değerine odaklandığını belirtmişlerdir. Bunun yanında, öğrencilere göre öğretmenler çalışkanlık ve sorumluluk değerlerine dikkat etmektedirler. Memişoğlu (2013) tarafından yapılan çalışmada da, öğretmenlerin en çok sorumluluk, hoşgörü, dürüstlük, saygı değerlerine ağırlık verdiği ortaya çıkarılmıştır. Benzer şekilde, Çelikkaya ve Filoğlu (2014), öğretmenlerin en çok dürüstlük, saygı ve sorumluluk değerlerinin kazandırılmasını tercih ettiklerini belirtmişlerdir. Çalışmalara bakıldığında, öğretmenlerin üzerinde durduğu değerlere ilişkin çıkan sonuçların birbirine benzer olduğu görülmektedir.

Değer kazandırma yöntemi olarak bütün katılımcıların öğretmenin rol-model olması, yaşantısıyla buna örnek olması gerektiğini vurguladığı görülmektedir. Kurtdede Fidan'ın (2009) yapmış olduğu çalışmada da öğretmen adayları, öğretmenin öncelikle rol-model olması gerektiğini belirtmişlerdir. Balcı ve Yanpar Yelken (2013) ve Memişoğlu (2013) yaptıkları çalışmada, öğretmenlerin değer eğitiminde en etkili bulduğu yöntemler arasında "rol-model olmayı" ilk sıralarda tercih ettiklerini belirtmişlerdir. Sosyal öğrenme kuramına göre, sosyal imalardan öğrenilen yeni davranış şekilleri, öğrenmenin kaçınılmaz yoludur. Bunun nedeni, öğrencilerin, onların öğretmenlerine benzer davranışlar sergilemeleri, onlardan etkilenmeleridir (Bandura, 1971). Yapılan çalışmaların sonuçlarından yola çıkarak, öğrencilerin davranışlarını şekillendirmelerinde öğretmenlerin örnek davranış sergilemelerinin önemli bir etkiye sahip olduğu söylenebilir.

Öğretmenler, öğretmen adayları ve öğrenciler, değerlerin örnek olay veya kişilerle beraber anlatılmasında hemfikirdirler. Bu yöntemin kullanımında, seçilecek olan kişi veya olayın, değeri yansıtması ve olabildiğince objektif sunulması önem arz etmektedir. Öğretmen adayları ile yapılan çalışmalarda (Yazıcı ve Aslan, 2011; Yıldırım, 2014), Sosyal Bilgiler ders kitaplarına belli değerleri yansıtması amacıyla konulmuş tarihi şahsiyetler/kahramanlar ile öğretmen adaylarının algılarındaki söz konusu değeri yansıtan tarihi şahsiyetlerin/kahramanların çoğunlukla farklı olduğu tespit edilmiştir.

Öğretmenler doğrudan aktarım yöntemini (telkin etme) kullanmadıklarını belirtseler de, öğretmen adaylarının gözlemlerine göre öğretmenler en çok bu yaklaşımı kullanmaktadırlar. Veugelers'e (2000) göre, öğretmenler ne kadar telkin etmek istemese bile, seçtikleri ders yöntem ve tekniği bile, öğretmenin değerlerini yansıtmaktadır. Bununla birlikte, öğrencilerin ve velilerin bekledikleri yöntemler arasında da telkin etme yaklaşımı yer almaktadır.

Genel olarak bakıldığında, ortaya çıkan sonuçlara göre, değer eğitiminin verilmesi öncelikle ailenin daha sonra okulun sorumluluğundadır. Değerlerin kazanımı, bireyin hem kendini tanıması hem de topluma uyum sağlaması için gereklidir. Çocuğun değerleri kazanmasında, ailenin sorumluluğu olduğu kadar, öğretmenlerin de sorumluluğu vardır. Bu noktada, öğretmenin ve ailenin, hatta okul yönetiminin hem toplumun varolan değerlerinin nesilden nesile aktarımı için hem de mutlu bireylerin yetişmesi için ortak bir değerler eğitimi paydasında buluşması önemli görülmektedir.

Değerler eğitiminde aile katılımı ve öğrencinin aktifliği önemlidir. Bu sebeple, araştırma sonunda değerler eğitimini önemseyen eğitimcilere bazı öneriler sunulmaktadır. Öncelikle ailenin desteği ile değerler eğitimi gerçekleştirilmelidir. Öğretmenler, değer eğitiminde farklı yöntem ve teknikleri kullanabilirler. Bu yöntemler arasında yer alan telkin etme yöntemini de kullanmaktan çekinmemelidirler. Ancak yöntem tercihlerinde öncelikle öğrencilerini iyi tanımalı ve ılımlı bir sınıf ortamı oluşturmalıdırlar. Bunun yanında öğrencilere dersi sevdirmeyi unutmamalıdırlar. Öğretmenler, tutum ve davranışları konusunda, öğrencilerin ve velilerin beklentilerini anlamaya çalışmalı ve gerekli özdenetimi sağlamalıdırlar. Ayrıca araştırmacılara ve ilgili alanda karar vericilere bazı öneriler sunulmuştur. Buna göre, araştırmanın kapsamı genişletilebilir ve daha fazla katılımcıya 
ulaşılabilir. Çalışma verilerinden yararlanılarak farklı bilimsel yöntemler ile araştırma sonuçları zenginleştirilebilir.

\section{KAYNAKÇA}

Adıgüzel, O. C. \& O. Ergünay. (2012). Türkiye'de gerçekleştirilen lisansüstü tezlerin eğitim bilimleri ve öğretmen yetiștirme perspektifinden incelenmesi. Elektronik Sosyal Bilimler Dergisi, 11(41), 18-33.

Ağırakça, G. P. (2012). Tanzimat'tan Cumhuriyet'e mekteplerde ahlâk eğitim ve öğretimi. (Yayımlanmamış doktora tezi). Marmara Üniversitesi, İstanbul.

Akbaş, O. (2008). Değer eğitimi akımlarına genel bir bakış. Değerler Eğitimi Dergisi, 6(16), 9-27.

Akyüz, Y. (2011). Türk eğitim tarihi (19. Baskı). Ankara: Pegem Akademi Yayınevi.

Ali, İ. (1317). Rehber-i ahlâk. İstanbul.

Balcı, F.A. \& T. Yanpar Yelken. (2013). İlköğretim sosyal bilgiler programında yer alan değerler ve değer eğitimi uygulamaları konusunda öğretmen görüşleri. Ahi Evran Üniversitesi Kırşehir Eğitim Fakültesi Dergisi, 14(1), 195-213.

Bandura, A. (1971). Social learning theory. Newyork: General Learning Press.

Binat, T. (1971). Milli kültür ve ahlak. İstanbul: Yörük Matbaası.

Çağlar, A. (2005). Okul öncesi dönemde değerler eğitimi. M. Sevinç (Ed.) Erken Çocuklukta Gelişim ve Eğitimde Yeni Yaklaşımlar. İstanbul: Morpa Kültür Yayınları.

Çelikkaya, T. \& S. Filoğlu. (2014). Sosyal bilgiler öğretmenlerinin değere ve değer eğitimine ilişkin görüşleri. Kuram ve Uygulamada Ĕgitim Bilimleri, 14(4), 1541-1556.

Çengelci, T. (2010). Illköğretim beşinci sınıf sosyal bilgiler dersinde değerler eğitiminin gerçekleştirilmesine iliş̧kin bir durum çalışması. (Yayımlanmamış doktora tezi). Anadolu Üniversitesi, Eskişehir.

Christien, L.B., Johnson, R. B. \& L. A. Turner. (2015). Araştırma yöntemleri, desen ve analiz (A. Aypay, çev.). Ankara: Anı Yayıncllık. (Orijinal basım 2014).

Dale, N. T. (1994). Values education in American secondary school. Kuztown University Education Conference (16 Eylül 1994).

Değer Nedir? http://dictionary.reference.com, http://www.oxforddictionaries.com, http://tdk.gov.tr/ adreslerinden 05.05.2015 tarihinde alınmıștır.

Demirhan İșcan, C. (2011). Values education and some suggestions to teachers. Hacettepe Üniversitesi Eğitim Fakültesi Dergisi, 40, 245-255.

Durkheim, E. ( 2010). Ahlak eğitimi (2. Baskı). (0. Adanır çev.). İstanbul: Say Yayınları.

Ekşi, H. \& A. Katılmış. (2014). Karakter eğitimi el kitabı (3. Baskı). Ankara: Nobel Akademik Yayınclık.

Elbir, B. \& C. Bağcı. (2013). Değerler eğitimi üzerine yapılmış lisansüstü düzeyindeki çalışmaların değerlendirilmesi. Turkish Studies, 8(1), 1321-1333.

Erdem, A. R. (2003). Üniversite kültüründe önemli bir unsur: Değerler. Değerler Eğitimi Dergisi, 1(4), 55-72.

Ersoy, F. (2013). Sosyal bilgiler dersiyle bütünleștirilmiş aile katılımlı karakter eğitimi programının geliştirilmesi. (Yayımlanmamış yüksek lisans tezi). Marmara Üniversitesi, İstanbul.

Ersoy, F. \& T. Şahin. (2012). Sosyal bilgiler ders kitaplarının değerler eğitimi yaklaşımları açısından incelenmesi. Kuram ve Uygulamada Eğitim Bilimleri, 12(2), 1535-1558.

Gömeç, S. (1997). Kök Türk tarihi. Ankara: Türksoy Yayınları.

Gültekin, F. (2014). Values within the context of social sustainability. The Science and Education at the Beginning of the 21st Century in Turkey, (vol.4). (ed. Mortan, K., Hristov, I., Strelova, O., Kostova, Z.), Sofia: Kliment Ohridski University Press.

Gündüz, M. (2013). Osmanlı eğitim mirası. Ankara: Doğubatı Yayınları.

Izgar, G. (2013). İlköğretim okulu 8. sınıf öğrencilerine uygulanan değerler eğitimi programının demokratik tutum ve davranışlara etkisi. (Yayımlanmamış doktora tezi). Necmettin Erbakan Üniversitesi, Konya.

İlk mektepler müfredatı. (1340). Maarif Vekâleti, İlk Tedrisat Dairesi, İstanbul.

Kafesoğlu, İ. (2014). Türk milli kültürü (36. Baskı). İstanbul: Ötüken Yayınları.

Karasar, N. (2014). Bilimsel araștırma yöntemi (26. Basım). Ankara: Nobel Akademik Yayıncılık.

Katılmış, A. (2010). Sosyal bilgiler dersindeki bazı değerlerin kazandırılmasına yönelik bir karakter eğitimi programının geliştirilmesi. (Yayımlanmamış doktora tezi). Marmara Üniversitesi, İstanbul.

Katılmış, A., Ekşi, H. ve C. Öztürk. (2011). Sosyal bilgiler ders kazanımlarıyla bütünleştirilmiş karakter eğitimi programının etkililiği. Kuram ve Uygulamada Ĕgitim Bilimleri, 11(2), 839-859.

Kaya, U. (2013). Tanzimat'tan Cumhuriyet'e Osmanlı'da ahlâk eğitimi (1. Baskı). İstanbul: Dem Yayınları.

Keskin, Y. (2008). Türkiye'de sosyal bilgiler öğretim programlarında değerler eğitimi: Tarihsel gelişim, 1998 ve 2004 programlarının etkililiğinin araştırılması. (Yayımlanmamış doktora tezi). Marmara Üniversitesi, İstanbul.

Keskin, Y. (2010). Sosyal bilgiler derslerinde değerler eğitimin yeri ve önemi. Eğitime Bakış, 6(18), 68-72. 
Kinnier, R. T., Kernes, J.L. \& T. M. Dautkeribes. (2000). A short list of universal moral values. Counseling and Values, 45, 4-16.

Kohlberg, L. (1975). The cognitive-developmental approach to moral education. PhiDelta Kappan, 56(10), 670677.

Kurtdede Fidan, N. (2013). Sosyal bilgiler dersinde değerler eğitimi: Nitel bir araştırma. The Journal of Academic Social Science Studies, 6(3), 361-388.

Kurtdede Fidan, N. (2009). Öğretmen adaylarının değer öğretimine ilişkin görüşleri. Kuramsal Eğitimbilim, 2(2), 1-18.

Lickona, T. (1993). The return of character education, Educational Leadership, 51(3), 6-11.

Lickona, T. (1997). The teacher's role in character education, Journal of Education, 179(2), 63-79.

MEB (2005). Sosyal bilgiler ders programı. URL: http://ttkb.meb.gov.tr/program2.aspx

Mehmedoğlu, A. U. (2006). İlahiyat fakültesi öğrencilerinin değer yönelimleri ve dindarlık-değer ilișkisi. Marmara Üniversitesi İlahiyat Fakültesi Dergisi, 30(1), 133-167.

Memişoğlu, H. (2013). İlköğretim 4. ve 5. sınıf öğretmenlerinin sosyal bilgiler dersinde değerler eğitimine ilişkin görüşleri. The Journal of Academic Social Science Studies, 6(3),405-425.

Nurdoğan, A. M. (2005). Osmanlı modernleşme sürecinde ilköğretim (1869-1922). (Yayımlanmamış doktora tezi). Marmara Üniversitesi, İstanbul.

Oğuz, E. (2012). Öğretmen adaylarının değerler ve değerler eğitimine ilişkin görüşleri. Kuram ve Uygulamada Ĕ̆itim Bilimleri, 12(2),1309-1325.

Demirbaş, Ç. Ö. \& T. Çelikkaya. (2012). Sosyal bilgiler öğretmen adaylarının programdaki değerlere ilişkin algisal farkındalıkları. The Journal of Academic Social Science Studies, 5(8),415-427.

Schrier, K. (2015). EPİC: a framework for using video games in ethics education. Journal of Moral Education, 44(4), 393-425.

Schwartz, S. H. (1992). Universal in the content and structure of values: Theoretical advances and empiricial tests in 20 countries. "Advances in Experimental Social Psychology" Ed. M. P. Zanna, vol.25, America: Academic Press.

Superka, D. P., Ahrens, C., Hedstorm, J.E. \& Johnson, P.L. (1976). Values education sourcebook: conceptual approaches, materials analyses, and an annotated bibliography. Colorado: Socal Science Education Consortuim, ERIC Clearinghouse for Social Studies/Social Science Education.

Tay, B., Durmaz, F. Z. \& M. Şanal. (2013). Sosyal bilgiler kapsamında öğrencilerin değer ve değerler eğitimine ilișkin görüșleri. Gazi Üniversitesi Gazi Eğitim Fakültesi Dergisi, 33(1),67-93.

Tay, B. \& Yıldırım, K. (2009). Sosyal bilgiler dersinde kazandırılması amaçlanan değerlere ilişkin veli görüşleri. Kuram ve Uygulamada Ĕ̆itim Bilimleri, 9(3), 1499-1542.

Tonga, D. \& S. Uslu. (2015). Sosyal bilgiler dersinde kazanım-değer ilişkisi. Ahi Evran Üniversitesi Kırşehir Eğitim Fakültesi Dergisi, 16(1),91-110.

Topkaya, Y. \& H. Tokcan. (2013). Sosyal bilgiler öğretim programının belirlediği değerlerin 6. sınıf sosyal bilgiler ders kitaplarına yansıma düzeylerinin karşılaştırılması. Uluslararası Avrasya Sosyal Bilimler Dergisi, 10(4), 33-43.

Ulusoy, K. \& B. Dilmaç. (2014). Değerler eğitimi (2. Baskı). Ankara: Pegem Akademi.

Veugelers, W. (2000). Different ways of teaching values. Educational Review, 52(1), 37-46.

Yalar, T. (2010). Illköğretim sosyal bilgiler programında değerler eğitiminin mevcut durumunun belirlenmesi ve öğretmenlere yönelik bir program modülü geliştirme. (Yayımlanmamış doktora tezi). Mersin Üniversitesi, Mersin.

Yaman, H., Taflan, S. \& S. Çolak (2009). İlköğretim ikinci kademe türkçe ders kitaplarında yer alan değerler. Değerler Eğitimi Dergisi, 7(18), 107-120.

Yazar, T. (2012). Öğretmen adaylarının değerler hakkındaki görüșleri. Pegem Ĕ̆itim ve Öğretim Dergisi, 2(1), 61-68.

Yazıcı, S. \& A. Yazıcı. (2011). Felsefi, psikolojik ve eğitim boyutlarıla karakter. Konya: Çizgi Kitabevi.

Yazıcı, S. \& M. Aslan. (2011). Using heroes as role models in values education: A comparison between Social Studies Textbooks and Prospective Teacher' choice of hero or heroes. Kuram ve Uygulamada Eğitim Bilimleri, 11(4), 2173-2188.

Yıldırım, K. (2009). Türk sınıf öğretmenlerinin değerler eğitimine ilişkin deneyimleri: Fenomonolojik bir yaklașim. Eurasian Journal of Educational Research, 35, 165-184.

Ylldirım, S. G. (2014). A social learning model in the values teaching: Use of the hero/heroine. The Science and Education at the Beginning of the 21st Century in Turkey, (vol.4). (ed. Mortan, K., Hristov, I., Strelova, O., Kostova, Z.), Sofia: Kliment Ohridski University Press.

Yılmaz, S. (2013). Sosyal bilgiler dersinde kazandırılması amaçlanan değerlere ilişkin öğretmen adayı görüşleri. Adıyaman Üniversitesi Sosyal Bilimler Enstitüsü Dergisi, 6(14), 645-679. 
Yiğittir, S. \& E. Yalçınkaya. (2009). Değer eğitiminde örnek bir uygulama: İyilik günlükleri. I. Ulusal İyilik Sempozyumu (20-21 Haziran), 153-163, Elazı̆̆. 